\title{
Antibacterial Activity of Fungal Endophytes Isolated from Wattakaka volubilis (Linn.f.), A medicinal plant from Telangana, India.
}

\author{
A. Aruna ${ }^{1}$, M. Abhinesh ${ }^{2}$, V. Bhavani ${ }^{3}$ and V. Krishna Reddy ${ }^{* 4}$ \\ ${ }^{1}$ Department of Botany, Kakatiya University, Warangal, Telangana, India \\ ${ }^{2}$ Department of Botany, Kakatiya University, Warangal, Telangana, India \\ ${ }^{3}$ Department of Botany, Kakatiya University, Warangal, Telangana, India \\ ${ }^{4}$ Department of Botany, Kakatiya University, Warangal, Telangana, India \\ *Corresponding author: vkreddyku@gmail.com,Tel:+919885511837
}

Available online at: www.isroset.org

Received: 23/Jan/2019, Accepted: 10/Feb/2019, Online: 28/Feb/2019

\begin{abstract}
Endophytic fungi are known to produce a wide range of metabolites of pharmacological importance. Endophytes associated with medicinal plants are targets for intensive research. This research paper deals with the endophytic fungi isolated from Wattakaka volubili also known as Dudipala, a high valued medicinal plant in traditional medicine. A total of 39 fungal species representing mostly imperfect fungi were isolated from different plant parts. The fungal species varied with geographic and environmental conditions of the same host species. Among different genera, Aspergillus, Penicillium, Fusarium, Phoma and mycelia sterilia were dominant. Solvent extracts of five endophytic fungi viz Aspergillus oryzae, Diplodia andamanensis, Fusarium graminearum, Penicillium rubrum and Rhizoctonia bataticola were tested against four human pathogenic bacteria, Antibacterial activity varied with the fungus as well as solvent. The inhibitory activity is very prominent on E.coli. Hexanol and chloroform extracts activity is very close to streptomycin. In light of these observations it is recommended that the pure extracts need to further test for antibacterial activity.
\end{abstract}

Keywords-Wattakaka volubilis, endophytic fungi; antibacterial activity.

\section{INTRODUCTION}

Endophytic fungi have been found in all woody plants that have been examined for endophytes [1, 2, and 3]. Studies of fungal endophytes in trees, shrubs and ferns reveal that individual species and even individual plants typically harbor scores of fungal species [4, 5]. Despite their great diversity and abundance, their interactions with their host plants have received less attention. In addition, there has been little attempt to integrate ecological and evolutionary aspects of the endophytic fungi [6]. Endophytic fungi are known to produce a wide range of metabolites that find applications in human health [7]. A recent comprehensive study has indicated that $51 \%$ of biologically active substances isolated from endophytic fungi were previously unknown. The novel bioactive compounds include anticancer, anti microbial, antioxidants, immunomodulators, anti-inflammatory, etc. As a result, a number of investigators devoted their attention to investigate the endophytes from different plant species.

Wattakaka volubilis (= Dregea volubilis; Marsdenia volubilis) (family Asclepiadaceae) commonly Known as Jutiki' is a tall, woody climber occurring throughout the hotter parts of India. Only one species is reported from India. It is a well recognized medicinal plant in folklore and traditional medicines like Ayurveda, Siddha and Unani [8, 9]. Traditionally, leaves are used as an application to boils and abscesses. Different plant parts are used in cold, eye diseases and snake bites [10]. The roots and tender stalks are considered emetic and expectorant [11]. Many phyto constituents like steroids, steroidal glycosides, sugars, triterpenoids, flavonoids, phenolic compounds and some alkaloids are found in the plant [12] .Medicinal plants are also reported to host endophyte fungi that are known to be involved in the co-production of active metabolites [13]. 
These fungi may also contribute to the biological activities exhibited by the plants.

Though there are reports on endophytic fungi associated with ethnomedicinal plants $[14,15]$ antibacterial activity has been a major challenge to health care system globally. Studies have shown that microbes have developed resistance to antibiotics through various molecular mechanisms such as prevention of access to drug targets and modification of the drug [16, 17]. Thus this global problem has led to the increase in researches featuring endophytic fungi, particularly those isolated from medicinal plants for their potential as source of new antibiotics. Reports on the bioactivity of endophytic fungi isolated from Wattakaka volubilis are scarce. The present study is aimed to assess the efficiency of endophytic fungi associated with this plant for antimicrobial activity.

\section{MATERIAL AND METHODS}

\section{Collection of plant samples:}

Tissue samples of root (40), stems (80), leaves (70) and bark (50) were collected from healthy Wattakaka volubilis plant from different geographic locations of Telangana state, India (Warangal $17^{\circ} 58 \mathrm{~N}, 79^{\circ} 35 \mathrm{E} 263 \mathrm{~m}$; Karimnagar $18^{\circ} 26 \mathrm{~N} 79^{\circ} 07 \mathrm{E} 277 \mathrm{~m}$ and Khammam $17^{\circ} 14 \mathrm{~N}$, $80^{\circ} 08 \mathrm{E} 139 \mathrm{~m}$ elevation ) in different seasons (summer, winter and rainy ) during 2017. Healthy and old mature plant parts were carefully chosen for sampling. Samples were placed in Ziploc bags, maintained at $4^{\circ} \mathrm{C}$ in on thermocol ice box during transport and processed within 24 hours.

\section{Isolation of fungal endophytes:}

The plant parts were washed thoroughly in tap water followed by sterilized water for few minutes to remove dirt and debris [18]. A total 1,920 number of segments were selected for different parts of plant sampling. In root maturation zone of elongation were cut in to vertically in 4 to $8 \mathrm{~cm}$ segments, The mature internodal parts of stem were collected and cut in to $0.4-0.6 \mathrm{~cm}$. Healthy and mature leaves lateral parts and midrib were cut into approximately $1 \mathrm{~cm}$ segments.[19]. The mature and healthy bark samples were cut in to the 1.5-2.0 above ground level [20].

The samples from leaves were washed previously with neutral detergent and rinsed with sterile water .They were then immersed in $70 \%(\mathrm{v} / \mathrm{v})$ alcohol for $1 \mathrm{~min}, 2 \%$ sodium hypochlorite for $3 \mathrm{~min}$ and again in sterile water for
2 min. Surface sterilization of stem, root, and bark parts were carried out by Fisher [21,22] method. The segments were immersed first in $75 \%$ ethanol for 60 seconds, followed by $4 \%$ sodium hypochlorite for 180 seconds, again in $75 \%$ ethanol for 30 seconds and finally rinsed in sterile distilled water for 10 seconds. The samples were kept on sterile filter paper to remove excess moisture. The externally sterilized segments were placed on agar plates (potato dextrose agar medium) supplemented with $120 \mathrm{mg}$ of streptomycin per liter, and then Petri dishes were sealed using parafilm.

\section{Identification:}

Each Petri dish containing 4 segments was incubated at $27 \pm 2{ }^{\circ} \mathrm{C}$ at 12 -h light/dark cycle [23]. After 712 days, the petri-dishes were monitored every day to check the growth of endophytic fungal colonies from the plant sample. The sample fragments were isolated and transferred to fresh tubes of PDA slants for preservation of fungal isolates and were stored at $4^{\circ} \mathrm{C}$ for further studies. Colony morphology of each fungus was recorded. Slides of fungal colonies were made with lactophenol cotton blue and observed under microscope. Mycelia, spore characteristics were recorded. Photomicrographs were taken under fluorescent microscope and fungi were identified with the help of standard manuals [24, 25].

\section{Fungal culture and extraction:}

Fungal crude extract was prepared using the protocol of Radji et al., 2011 [26]. Prospective endophytic fungi isolates were inoculated into $1000 \mathrm{ml}$ Erlenmeyer flasks containing $450 \mathrm{ml}$ of potato dextrose broth. (450 $\mathrm{g}$ of potato extract, $20 \mathrm{~g}$ of dextrose, and $20 \mathrm{~g}$ of sucrose in $1000 \mathrm{ml}$ of distilled water) and incubated at $27 \pm{ }^{\circ} \mathrm{C}$ for 21 days under stationary conditions with intermittent shaking. The fungal broth culture was filtered through whatman no.1 filter paper to give clear filtrate and mycelia and exposed to the extraction process. Liquid supernatant was extracted with an equal volume of organic solvents (Chloroform, Hexane, and Methanol) and the extract was then evaporated under reduced pressure using rotary evaporator. The crude extracts were used for preliminary evaluation of antibacterial activity using disc diffusion method.

\section{Antimicrobial activity:}

The antimicrobial activity of Crude extract of fungal endophytes was carried out by disc diffusion method. The 
phyto pathogenic bacteria were selected, two gram positive bacteria Staphylococcus aureus (ATCC- 6538) and Micrococcus luteus ATCC-4698) and two gram negative bacteria Escherichia coli (ATCC-8739) and Klebsiella pneumonia (MTCC- 3384) were obtained from the Department of Microbiology (KU) Warangal, maintained on nutrient agar medium at $37^{\circ} \mathrm{C}$ and stored at $4^{\circ} \mathrm{C}$.

All bacterial suspension was standardized to contain approximately $1.5 \times 10^{8} \mathrm{CFU} / \mathrm{ML}$. The bacteria were inoculated on dried surface nutrient agar medium.

The dried crude extract from different solvents (Hexane, Methanol and Chloroform) of 5 different fungal species was dissolved in $0.1 \%$ acetone to a concentration of $100 \mathrm{mg} / \mathrm{ml}$. Then $30 \mathrm{ml}$ of the dissolved extract was pipeted to $5 \mathrm{~mm}$ diameter (Sterile whatman no 1 filter paper) circular discs and allowed to dry in incubator at $35^{\circ} \mathrm{C}$. In each plate three paper disks with the extract were placed and negative (sterilized water) and positive (Streptomycin) control was separately maintained. All plates were incubated at $37^{\circ} \mathrm{C}$ in incubator for 24 hours. After incubation the diameter of the zone of inhibition (ZOI) was measured using a measuring scale.

\section{RESULTS}

Geographic distribution and variation in climatic conditions affect both host and the endophytes. Environmentally, the endophytes may be metabolically aggressive by affecting host defense chemicals. Synthetic ability of endophytes may account for hostile environment faced by the host. Thos perhaps explains the apparent anamoly observed when a species of endophyte isolated from a host plant produces a bioactive compound but fails to do so when isolated from another plant species [27]. It may also be true for the endophytes of species growing in different geographical locations and experiencing different climatic conditions [28]. Hence it is not only host plant as well as endophytes important but also ecosystem in which they are growing since in different ecosystems. The mode of interaction between the host and endophyte may shift drastically; keeping these aspects in mind three different geographic locations were selected. Similarly samples were collected in different seasons (Table - I). A critical observation of the table reveals that there is a variation in the geographic co-ordinates. The difference between the altitudes of sampling locations varied between 98 and 441, that implies great variation. Average annual and seasonal rainfall also varied significantly. The rainfall shows profound effect on the survival, growth and reproduction of plant species indirectly effecting the endophytic diversity and distribution. The temperatures of three selected zones varied seasonally and also according to location. The difference in different seasons was $\pm 3{ }^{\circ} \mathrm{C}$. The variation of seasonal temperature is about $12{ }^{\circ} \mathrm{C}$.

In the present investigations, an attempt has been made to isolate the endophytic fungi from different organs of the test plant i.e. Wattakaka volubilis. For this purpose random samples of plant parts were selected and the isolations of endophytic fungi were made. Colonization frequency, dominant frequency and endophytic infection rates (Table-2) were estimated from the number of fungi isolated from four plant parts; root, stem, leaf and bark. A total of 320 root segments were examined for endophytic fungi, out of which 107 segments were found to be positive for one or other funge. Colonization frequency varied with the fungus. The highest colonization frequency was observed with Aspergillus species. Similarly, Alternaria, Aspergillus and Penicillium species were dominant out of many fungi isolated. Endophytic infection rates were noticed for only few fungi. In case of the stem out of 640 segments isolated 143 were found to be positive for endophytic fungi. The endophytic fungi isolated from stem were not exactly similar to root. Same in the case with colonization frequency, dominant frequency and endophytic infections rates. The percentage of positive segments in leaf was almost equal to stem. Colonization frequency, dominant frequency and endophytic infection rates of leaf varied with the fungi and they were comparatively less than the corresponding parameter values of stem. In bark, the positive segment for endophytic colonization was 22.5. Bark appears to be colonized by fewer fungi. Likewise, CF, DF and EIR values were also found to be less than root, stem and leaf. Colonization by fewer fungi and less frequencies can be attributed to dry conditions of the bark than with other parts of the plant.

Qualitative analysis of the endophytic fungi associated with different parts of the plant reveals that roots are colonized by maximum number of fungal species followed by stem, bark and leaf. However the fungal species varied with the plant parts. For example Alternaria species were recovered from the root and stem but not from leaf and bark. Among different genera, Aspergillus, Penicillium, Fusarium, Phoma and Mycelia sterelia were dominant. Interestingly mycelia sterelia could not be isolated from the leaf segments. 


\section{Antibacterial Assay:}

Many endophytic fungi have been reported to produce novel antibacterial, antifungal, antiviral, anti - inflammatory, antitumor and other compounds. The production specificity of these compounds can partly be attributed to host from an ecological perspective. In the present investigation five endophytic fungi viz. Aspergillus oryzae, Diplodia andamanensis, Fusarium graminarium, Penicillium rubrum and Rhizoctonia bataticola, the most frequently occurring fungi from different plant parts were selected and extractions made in three different solvent, i. e hexane, chloroform and methanol were tested for antibacterial activity against two Gram +ve (M.luteus and S.aureus) and two Gram -ve (E.coli and K.pneumoniae) bacteria. The results are presented in (Table - 3). A critical perusal of the table reveals that all the extracts have shown some anti bacterial activity against all the four test bacteria. However, the antibacterial activities varied with endophtye, the solvent used for extraction and also test bacterium. Chloroform extracts of A. oryzae have shown activity on M.luteus but not on S.aureus. All the extracts from three solvents inhibited the growth of E.coli and interestingly but not on K.pneumoniae. All three extracts of Diplodia andamanensis have inhibited the growth of three test bacteria M.luteus, S. aureus and E. coli but not on K.pneumoniae. In contrary, hexane and methanol extract of $F$. graminarium have shown inhibitory activity against $S$. aureus and E. coli respectively. All three types of extracts of $P$. rubrum have shown antibacterial activity on three bacteria but not on S.aureus. Further, the inhibitory activity is very prominent on E. coli and hexane and chloroform activity is very close to Streptomycin. Solvents extracts of R.bataticola have shown inhibitory activity against $S$. aureus but not against all the three remaining bacteria. Even that activity was also very poor. In all the cases wherever inhibitory activity was observed it was far less than the control streptomycin (10ug/ml).

A comparison of efficacies of three solvents reveals that there is not much difference as far as the antibacterial properties are concerned. However few variations could be observed with methanol extracts of four endophytic fungi have shown inhibitory activity. In contrary the same solvent extract of $P$. rubrum has shown antibacterial activity against K.pneumoniae.

\section{DISCUSSION}

Plants serve as a reservoir of large numbers of microorganisms (fungi and bacteria) known as endophytes
[29]. Endophytic fungi are an ecological, polyphyletic group of highly diverse fungi, mostly belonging to ascomycetes and anamorphic fungi $[30,31]$. It has been estimated that there may be as many as one million different endophytic fungal taxa, thus endophytes may be hyperdiverse [32]. The host endophyte relationship cab be described in terms of host specificity or host preference [33, 34]. Host specificity implies that complex biochemical interactions occur between host and its associated hosts [35, 36]. Endophytes are able to colonize multiple host species of the same plant family within the same habitat. Similarly, the endophytes of the same species growing in different habitat and environmental conditions may vary. In this context Tan and Zou and Schulz [37, 38] felt that more attention should be given to studying endophytic biodiversity, the chemistry and bio activity of endophytic metabolites, and the relation between endophytes and their host plants, against this information. In the present investigations endophytic fungi of selected plants growing in different geographical locations and also different seasons were studied. Similarly, the endophytic fungi from different plant parts were investigated.

Antimicrobial metabolites (Antibiotics) are low molecular weight organic compounds produced by microorganisms. Many endophytic fungi were demonstrated to produce many known and novel antibiotics [39]. They are produced by the endophytes as on adaptation for specific functions in their ecological niche [40]. It is believed that screening for antimicrobial compounds from endophytes is a promising way to overcome the increasing threat of drug resistant microbes of human and plant pathogens [41].In this context endophytic fungi associated with proved medicinal plants are of great attraction [42] reported 30\% of tested isolates exhibited and antifungal activity. Several studies have confirmed that crude extracts of endophytic fungi exhibited anti bacterial activity [43] published a remarkable review of anti microbial metabolites isolated from endophytes. They further concluded that there is a great opportunity to utilize endophytes as a new source of production of reliable and novel antimicrobial agents. In the present investigations, therefore, an opportunity was taken to screen some selected endophytic fungi against two Gram +ve and two Gram -ve bacteria.

\section{CONCLUSION}

The present investigations have demonstrated that the diverse endophytic fungi of $W$. volubilis varied with the host species, as well as geographic and environmental conditions 
of the same host species. It conveys the message that to get the full spectrum of endophytic fungi. It is essential to select the different host species as well as the same species growing in different locations. The present medicinal plant harboured a rich endophytic mycoflora in its different organs. Antimicrobial activity of endophytic fungi revealed that the extracts are capable of inhibiting bacteria, however with different capacities. The crude extracts were showing antibacterial activity, if the crude extracts purified they may show a high antibacterial activity. The work in this direction is in progress.

\section{ACKNOWLADGEENT}

Our sincere thanks are due to Head, Department of Botany, Kakatiya University for encouragement and facilities. Two of us AA and MA owe sincere gratitude to UGC, New Delhi for awarding Rajiv Gandhi National Fellowship.

\section{REFERENCES}

[01]. G.F. Bill. "Isolation and analysis of endophytic fungal communities from woody plants". See Ref. 126, pp. 31-65, 1996.

[02]. O. Petrini ."Fungal endophytes of tree leaves". See Ref. 4a, pp. 179-97, 1991.

[03]. S.C. Redlin and L.M. Carris LM. "Endophytic Fungi in Grasses and Woody Plants. Systematics, Ecology and Evolution". St. Paul: $\quad$ APS. pp.216, 1996.

[04]. D. Todd "The effects of host geno- type, growth rate, and needle age on the distribution of a mutualistic, endophytic fungus in Douglas-fir plantations". Can. J. For. Res.,18: pp.601-605, 1988.

[05]. B. Widler and E. Muller . "Untersuchun- gen uber endophytische Pilze von Arc- tostaphylos uva-ursi (L.) Sprengel (Eri- caceae)". Bot. Helv. 94: pp. 307-337, 1984.

[06]. K.E. Hammon and S.H. Faeth . "Ecology of plant-herbivore communities": a fun- gal component. Nat. 1: pp.197-208, 1992.

[07]. K.A. Salim , E. E1Beih AA, Abd, A. Rahman TM and Diwany. "Biology of endophyticfungi C". Research in Envi. and Applied Mycology 2 (1): pp.31- 82, 2012.

[08]. M. Thomas, P.T.A. Hepsibah , N.B.R. Prasad , and P. Sanjeev kumar. "Pharmacognostical and clinical Studies on Wattakaka volubilis (Linn.f.)”. Ancient Science of life 4: pp. 277-281, 1996.

[09]. S. Najafi . "Studies on Wattakaka volubilis (L.F.) stap". A medicinally important plant. Research journal of pharmaceutical, biological and chemical sciences. ISSN: 0975-8585, vol2, 2011.

[10]. K.M. Nadkarni . Indian materia medica. Popular Prakashan Pvt Ltd: Mumbai 1: pp. 465, 2009.

[11]. K.R. Kirtikar and B.D. Basu. Indian Medicinal plants Periodical experts book agency, Delhi, III, pp: 1635-1636, 2006

[12]. Anonymou, "The wealth of India, raw materials. National Institute of Science",Communication Information Resources, New Delhi, $\quad \mathrm{X}: S p-W$, pp. 564-565, 2003.

[13]. A. Alvin , K.I. Miller and B.A. Neilan. "Exploring the potential of endophytes frommedicinal plants as sources of antimicrobial compounds". Microbial Res, 169 (7): pp. 483-495, 2014.

[14]. R.K. Bhagobaty, S.R. Joshi and R. Kumar . "Penicillium verruculosum RS7PF: a root fungal endophyte associated with an ethno-medicinal plant of the indigenous tribes ofeastern India", African Journal Microbiological Research, vol.4, pp.766-770, 2010 .
[15]. A. Nath, S.R. Chattopadhyay and Joshi SR. "Biological activity of endophytic fungi of Rauwolfia serpentina Benth: A ethno

medicinal plant used in folk medicines in Northeast India", Proceedings of National Academy Sciences, India, Biological sciences, DOI 10.1007/s40011-013-0184-8, 2013.

[16]. N.L. Owen and N. Hundle. "Endophytes the chemical synthesizers inside plants". Sci pro.87 (2): pp. 79-99, 2004

[17]. J.M.A. Blair, M.A. Webber, A.J. Baylay, D.O. Ogbolu DO and L.J.V. Piddock . Molecular mechanisms of antibiotic resistance. Nat Rev Microbial, 13: pp. 42-51, 2015.

[18]. S. Selvanathan, I. Indrakumar and M. Johnpaul. "Biodiversity of the endophytic fungi Isolated from Calotropis gigantea (L.)" R .Br. R. Research in Sci and Techno3: pp. 94-100, 2011.

[19]. J.K. Dobranic , L.A. Johnson and Q.R. Alikhan . "Isolation of endophytic fungi from eastern larch (Larix laricina) leaves from New Brunswich", Canadian .Journal of Botany. 41: pp. 194-198, 1995.

[20]. J.P. Marcellano , S. Alyssa ,R. collanto and G.Fuentes . "Antibacterial Activity of Endophytic fungi Isolated from the Bark of Cinnamomum mercadoi". Pharmacogn j. 9 (3): pp. 405-409, 2017

[21]. P.J. Fisher, O Petrini and B.C. Sutton. "A comparative study of fungal endophytes in leaves xylem and bark of Eucalyptus nitens in Australia and England". Sydowia, 45: pp.338-345, 1993.

[22]. P.J. Fisher, O. Petrini , L.E. Petrini, and B.C. Sutton. "Fungal endophytes from the leaves and twigs of Quercus ilex $L$. from England Majorea and Switzerland". New Phytol. 127: pp. 133137, 1994.

[23]. T.S. Suryanarayanan, G. Venkatesan and T.S. Murali TS. "Endophytic fungal communities in leaves of tropical forest trees: $\quad$ Diversity and distribution patterns", Current Science 85 (4): pp.486 - 492, 2003.

[24]. K. Singh, J.C. Frisvad, U. Thrane and S. Mathur S. "An illustrated manual on identification of some seed-borne Aspergilli,

Fusaria, Penicillia”. pp. 31-69, 1991.

[25]. H. Barnett and B. Hunter. "Descriptions and illustrations of genera. Illustrated genera of imperfect fungi" $\left(4^{\text {th }} \mathrm{ed}.\right)$ American Phytopathological Society, St. Paul, MN, 1998.

[26]. M.Radji,A.Sumiati,R. Rachmayani and B.Elya.'Isolated antibacterial activity' African journal of Bioticnology $\mathbf{1 0}$ (1): pp. 103- 107, 2011.

[27]. G.A. Li JY, Strobel , R. Sidhu , W.M. Hess and E. Ford . "Endophytic taxol producing fungi from Bald Cypress Taxodium distichum”. Microbiology 142, pp. 2223-2224, 1996.

[28]. B. Paulus, J. Kanowski , P. Gadek andK.D. Hyde KD. "Diversity and Distribution of saprobic microfungi in leaf litter of on Australian tropical rainforest". Mycological Research 110: pp.1441 -1454, 2006.

[29]. C.W. Bacon and J.F. White. Microbial Endophytes. Marcel Deker, NewYork, USA, 2000.

[30]. Y. Huang, J. Wang, Z. Li, G Zheng,W. Su . "Antitumor and antifungal activities in endophytic fungi isolated from pharmaceutical plants Taxus mairei, Cephalataxus fortunei and Torreya grandis". FEMS Immunology and Medical Microbiology 31, pp.163- 167, 2001.

[31]. A.E. Arnold, "Understanding the diversity of foliar endophytic fungi: progress, challenges, and frontiers". Fungal Biology Reviews 21, pp.51-66, 2007.

[32]. W.Y. Huang,Y.Z. Cai , J. Xing , H. Corke and M. Sun ".Potential antioxidant resource: endophytic fungi isolated from traditional Chinese medicinal plants". Economic Botany 61, pp.14-30, 2007. 
[33]. D. Zhou and K.D. Hyde KD. "Host-specificity, host-exclusivity, and host-recurrence in saprobec fungi". Mycological Research 105, pp.1449-1457, 2001.

[34]. S.D. Cohen. "Host selectivity and genetic variation of Discula umbrinella isolates from two oak species: analyses of intergenic spacer region sequences of ribosomal DNA". Microbial Ecology 52, pp.463-469, 2006.

[35]. G. Strobel . "Endophytes as sources of bioactive products". Microbes and Infection 5, pp. 535-544, 2003.

[36]. G. Strobel and B. Daisy. "Bioprospecting for microbial endophytes and their natural products". Microbiology and Molecular Biology Reviews 67, pp.491-502, 2003.

[37]. R.X. Tan and W.X. Zou WX. "Endophytes: a rich source of functional metabolites". Natural Product Reports 18, pp. 448459, 2001.

[38]. B. Schulz, C. Boyl, S. Draeger and A.K. Römmert AK. "Endophytic fungi: a source of novel biologically active secondary metabolites". Mycological Research 106, pp.9961004, 2002.

[39]. B. Schulz, A.K. Römmert, U. Dammann ,D. Aust HJ and Strack . "The endophytehost interaction: a balanced antagonism"? Mycological Research 103, pp. 1275-1283, 1999.

[40]. A. Garcia, S.A. Rhoden, J. Bernardi-Wenzel, R.C. Orlandelli, J.L. Azevedo and J.A. Pamphile,. "Antimicrobial Activity of Crude Extracts of Endophytic Fungi Isolated from Medicinal Plant Sapindus saponaria L". J. of applied Pharma Sci 2 (10): pp.035-040, 2012.

[41]. Gu, Y. Wang, X. Sun and K.Tang. "Bioactive Natural Products from Endophytes": A Review1. Applied Biochemistry and Microbiology 44: pp. 136-142, 2008.

[42]. L. Yu H, Zhan, C. Li L, Zheng, L. Guo, L. Li W, P. Sun and L. Qin "Recent developments and future prospects of antimicrobial metabolites produced by endophytes". Microbiological Research 165: pp.437-449, 2010.

[43]. C. Li, H. Qing, Y. Zhang and Z. Zhao. "Screening for endophytic fungi with antitumor and antifungal activities from Chinese medicinal plants". World Journal of Microbiology and Biotechnology 21: pp. 1515-1519, 2005. 
Table.1 Sampling locations and their geographic and climatic features of Wattakaka volubilis (L.f.) Stapf

\begin{tabular}{|c|c|c|c|c|c|c|c|}
\hline & \multirow{2}{*}{ Sampling locations } & \multirow{3}{*}{ Sampling Season } & \multicolumn{2}{|c|}{ Geographic coordinates } & \multirow{2}{*}{ Altitude (m) } & \multirow{2}{*}{$\begin{array}{c}\text { Annual rainfall (mm) } \\
(2017)\end{array}$} & \multirow{2}{*}{ Mean temperature $\left({ }^{\circ} \mathrm{C}\right)$} \\
\hline & & & North & East & & & \\
\hline & Warangal & & $17^{\circ} 5824$ & $79^{\circ} 3538$ & 263 & & \\
\hline \multirow{4}{*}{ Zone-I } & Geesugonda & $\begin{array}{l}\text { Summer may-June } \\
\text { Rainy }\end{array}$ & $17^{\circ} 5758$ & $79^{\circ} 4147$ & 264 & $83.0 \mathrm{~mm}$ & $34.5^{\circ} \mathrm{C}$ \\
\hline & & July- October & & & & $244.8 \mathrm{~mm}$ & $25.3^{\circ} \mathrm{C}$ \\
\hline & Hasanparthi & $\begin{array}{c}\text { Winter } \\
\text { November February }\end{array}$ & $18^{\circ} 0403$ & $79^{\circ} 3132$ & 262 & Nil & $24.4^{\circ} \mathrm{C}$ \\
\hline & Narsampet & & $17^{\circ} 5544$ & $79^{\circ} 5345$ & 247 & & \\
\hline \multirow{4}{*}{ Zone-II } & Karimnagar & & $18^{\circ} 26^{\prime} 34^{\prime \prime}$ & $79^{\circ} 07^{\prime} 42^{\prime \prime}$ & 277 & & \\
\hline & Husnabad & $\begin{array}{c}\text { Summer may-June } \\
\text { Rainy } \\
\text { July- October }\end{array}$ & $18^{\circ} 07^{\prime} 50^{\prime \prime}$ & $79^{\circ} 12^{\prime} 30^{\prime \prime}$ & 365 & $\begin{array}{l}115.8 \mathrm{~mm} \\
63.5 \mathrm{~mm}\end{array}$ & $\begin{array}{l}33.3^{\circ} \mathrm{C} \\
27.5^{\circ} \mathrm{C}\end{array}$ \\
\hline & Mulkanoor & $\begin{array}{c}\text { Winter } \\
\text { November February }\end{array}$ & $18^{\circ} 05^{\prime} 14^{\prime \prime}$ & $79^{\circ} 22^{\prime} 11^{\prime \prime}$ & 313 & Nil & $27.3^{\circ} \mathrm{C}$ \\
\hline & Siddipet & & $18^{\circ} 09^{\prime} 08^{\prime \prime}$ & $78^{\circ} 56^{\prime} 36^{\prime \prime}$ & 441 & & \\
\hline \multirow{4}{*}{ Zone-III } & Khammam & & $17^{\circ} 14^{\prime} 51^{\prime \prime}$ & $80^{\circ} 08^{\prime} 58^{\prime \prime}$ & 139 & & \\
\hline & Kothagudum & $\begin{array}{c}\text { Summer may-June } \\
\text { Rainy }\end{array}$ & $17^{\circ} 32^{\prime} 30^{\prime \prime}$ & $80^{\circ} 37^{\prime} 27^{\prime \prime}$ & 115 & 36.2 & $34.0^{\circ} \mathrm{C}$ \\
\hline & Palvancha & $\begin{array}{l}\text { July- October Winter } \\
\text { November February }\end{array}$ & $17^{\circ} 35^{\prime} 54^{\prime \prime}$ & $80^{\circ} 41^{\prime} 50^{\prime \prime}$ & 99 & $\begin{array}{l}28.6 \\
\text { Nil }\end{array}$ & $\begin{array}{l}24.0^{\circ} \mathrm{C} \\
37.7^{\circ} \mathrm{C}\end{array}$ \\
\hline & Tallada & & $17^{\circ} 12^{\prime} 55^{\prime \prime}$ & $80^{\circ} 25^{\prime} 17^{\prime \prime}$ & 98 & & \\
\hline
\end{tabular}

Table. 2. Frequency of endophytic fungi isolated from Different parts of Wattakaka volubilis (L. f.) Stapf

\begin{tabular}{|c|c|c|c|c|c|c|c|c|c|c|c|c|c|c|c|c|c|}
\hline \multirow{2}{*}{$\begin{array}{l}\text { Sl } \\
\dot{\mathbf{N}} \\
\mathbf{0}\end{array}$} & \multirow[b]{2}{*}{$\begin{array}{c}\text { Fungal } \\
\text { endophytes }\end{array}$} & \multirow{2}{*}{$\begin{array}{c}\begin{array}{c}\text { Numb } \\
\text { er of } \\
\text { isolate } \\
\text { s }\end{array} \\
\end{array}$} & \multicolumn{3}{|c|}{ Root } & \multirow{2}{*}{$\begin{array}{c}\begin{array}{c}\text { Numb } \\
\text { er of } \\
\text { isolate } \\
\mathrm{s}\end{array} \\
\end{array}$} & \multicolumn{3}{|c|}{ Stem } & \multirow{2}{*}{$\begin{array}{c}\text { Numb } \\
\text { er of } \\
\text { isolate } \\
\quad \mathrm{s}\end{array}$} & \multicolumn{3}{|c|}{ Leaf } & \multirow{2}{*}{$\begin{array}{c}\text { Numb } \\
\text { er of } \\
\text { isolate } \\
\text { s }\end{array}$} & \multicolumn{3}{|c|}{ Bark } \\
\hline & & & $\underset{\%}{C F}$ & $\underset{\%}{D F}$ & $\underset{\%}{E I R}$ & & $\underset{\%}{C F}$ & $\underset{\%}{D F}$ & $\underset{\%}{E I R}$ & & $\underset{\%}{C F}$ & $\underset{\%}{D F}$ & $\underset{\%}{E I R}$ & & $\underset{\%}{C F}$ & $\underset{\%}{D F}$ & $\underset{\%}{E I R}$ \\
\hline 1. & $\begin{array}{l}\text { Alternaria } \\
\text { alternate }\end{array}$ & 5 & 1.5 & 4.6 & - & 5 & 0.7 & 3.4 & - & - & - & - & - & 8 & 2 & 8.8 & 0.7 \\
\hline 2. & A. fasciculate & 9 & 2.8 & 8.4 & 0.9 & - & - & - & - & - & - & - & - & - & - & - & - \\
\hline 3. & A. solani & 3 & 0.9 & 2.8 & - & - & - & - & - & - & - & - & - & - & - & - & - \\
\hline 4. & $\begin{array}{l}\text { Aspergillus } \\
\text { candidus }\end{array}$ & 7 & 2.1 & 6.5 & - & - & - & - & - & 15 & 2.6 & 0.1 & 0.8 & 4 & 1.2 & 5.5 & - \\
\hline 7. & A.niger & - & - & - & 1.5 & 3 & 0.4 & 2.0 & 0.1 & - & - & - & - & 5 & 1.2 & 5.5 & - \\
\hline 8. & A.ochraceus & - & - & - & - & 2 & 0.3 & 1.3 & - & - & - & - & - & - & - & - & - \\
\hline 9. & A.oryzae & 12 & 3.7 & 11.2 & - & 3 & 2.0 & 9.0 & 0.7 & 2 & 0.3 & 1.6 & - & 2 & 0.5 & 2.2 & - \\
\hline 10. & A.versicolor & 1 & 0.3 & 0.9 & - & - & - & - & - & - & - & - & - & - & - & - & - \\
\hline 11. & $\begin{array}{l}\text { Chaetomium } \\
\text { gracile }\end{array}$ & 4 & 1.2 & 3.7 & 2.5 & - & - & - & - & 3 & 0.5 & 2.4 & 0.3 & - & & & \\
\hline 15. & $\begin{array}{l}\text { Drechslera } \\
\text { spicifera }\end{array}$ & 6 & 1.8 & 5.6 & 0.9 & 14 & 2.1 & 9.7 & 0.6 & 5 & 0.8 & 0.4 & - & 3 & 0.7 & 3.3 & - \\
\hline 16. & $\begin{array}{l}\text { Diplodia } \\
\text { andamanensis }\end{array}$ & - & - & - & - & - & - & - & - & - & - & - & - & 11 & 2.7 & 12.2 & 0.5 \\
\hline 17. & $\begin{array}{l}\text { Epicoccum } \\
\text { nigrum }\end{array}$ & - & - & - & - & 5 & 0.7 & 3.4 & - & 11 & 1.9 & 8.8 & 1.4 & - & & & \\
\hline 18. & $\begin{array}{l}\text { Emericella } \\
\text { nidulans }\end{array}$ & - & - & - & - & 3 & 0.4 & 2.0 & - & 9 & 1.6 & 7.2 & 0.8 & - & & & \\
\hline 19. & $\begin{array}{l}\text { Fusarium } \\
\text { graminearum }\end{array}$ & 2 & 0.6 & 1.8 & - & - & - & - & - & 1 & 0.1 & 0.8 & - & 6 & 1.5 & 6.6 & - \\
\hline
\end{tabular}




\begin{tabular}{|c|c|c|c|c|c|c|c|c|c|c|c|c|c|c|c|c|c|}
\hline 20. & F.oxysporum & 1 & 0.3 & 0.9 & - & - & - & - & - & - & & & & - & - & - & - \\
\hline 21. & $\begin{array}{l}F . \\
\text { merismoides }\end{array}$ & - & - & - & - & 5 & 0.7 & 3.4 & 0.4 & 5 & 0.8 & 0.4 & - & 2 & 0.5 & 2.2 & - \\
\hline 22. & $F$. solani & - & - & - & - & 6 & 0.9 & 4.1 & 0.9 & - & & & & - & & & \\
\hline 23. & $\begin{array}{l}\text { Geotrichum } \\
\text { albidum }\end{array}$ & 5 & 1.5 & 4.6 & - & - & - & - & - & 10 & 1.7 & 8 & 0.8 & - & & & \\
\hline 24. & $\begin{array}{l}\text { Gliocladiopsis } \\
\text { sagariensis }\end{array}$ & 6 & 1.8 & 5.6 & 0.6 & - & - & - & - & 3 & 0.5 & 2.4 & - & - & & & \\
\hline 25. & $\begin{array}{l}\text { Helminthospor } \\
\text { ium sativum }\end{array}$ & 3 & 0.9 & 2.8 & - & 6 & 0.9 & 4.1 & - & - & - & - & - & - & & & \\
\hline 26. & $\begin{array}{l}\text { Neurospora } \\
\text { crassa. }\end{array}$ & 2 & 0.6 & 1.8 & - & - & - & - & - & - & & & & 4 & 1 & 4.4 & 0.2 \\
\hline 27. & $\begin{array}{l}\text { Nigrospora } \\
\text { sphaerica }\end{array}$ & - & - & - & - & 5 & 0.7 & 3.4 & 0.3 & - & & & & - & - & - & - \\
\hline 28. & $\begin{array}{l}\text { Penicillium } \\
\text { chrysogenum }\end{array}$ & 2 & 0.6 & 1.8 & - & 11 & 1.7 & 7.6 & 0.9 & 3 & 0.5 & 2.4 & - & 2 & 0.5 & 2.2 & - \\
\hline 29. & P. citrinum & 7 & 2.1 & 6.5 & 1.2 & 9 & 1.4 & 6.2 & - & - & - & - & - & & & & \\
\hline 30. & P. glabrum & 4 & 1.2 & 3.7 & - & - & - & - & - & - & - & - & - & 9 & 2.2 & 10 & 1.5 \\
\hline 31. & P. rubrum & - & - & - & -- & 1 & 0.1 & 0.6 & - & 18 & 3.2 & 14.4 & 1.6 & 1 & 0.2 & 1.1 & - \\
\hline 32. & $\begin{array}{l}\text { Phoma } \\
\text { crysanthemico } \\
l\end{array}$ & 1 & 0.3 & 0.9 & - & - & - & - & - & - & - & - & - & 6 & 1.5 & 6.6 & 1.2 \\
\hline 33. & $\begin{array}{l}\text { Phoma.destruc } \\
\text { tiva }\end{array}$ & 4 & 1.2 & 3.7 & - & - & - & - & - & 15 & 2.6 & 12 & 2.5 & - & - & - & - \\
\hline 34. & $\begin{array}{l}\text { Phoma } \\
\text { glomerata }\end{array}$ & - & - & - & - & & & & & 6 & 1.0 & 4.8 & - & 8 & 2 & 8.8 & 0.7 \\
\hline 35. & $\begin{array}{l}\text { Rhizoctonia } \\
\text { bataticola }\end{array}$ & 2 & 0.6 & 1.8 & - & 20 & 3.1 & 13.9 & 0.7 & 4 & 0.7 & 3.2 & - & 2 & 0.5 & 2.2 & - \\
\hline 36. & R.soloni & 8 & 2.5 & 7.4 & 1.8 & 5 & 0.7 & 3.4 & - & - & - & - & - & - & & & \\
\hline 37. & $\begin{array}{l}\text { Sterile } \\
\text { mycelium } 1\end{array}$ & - & - & - & - & 8 & 1.2 & 5.5 & 1.2 & - & - & - & - & 5 & 1.2 & 5.5 & 0.5 \\
\hline 38. & $\begin{array}{l}\text { Sterile } \\
\text { mycelium } 2\end{array}$ & 2 & 0.6 & 1.8 & - & - & - & - & - & - & - & - & - & 2 & 0.5 & 2.2 & - \\
\hline 39. & $\begin{array}{l}\text { Sterile } \\
\text { mycelium } 3\end{array}$ & 3 & 0.9 & 2.8 & 0.3 & 4 & 0.6 & 2.7 & - & - & - & - & - & - & - & - & -- \\
\hline 40. & Total \% & \multicolumn{4}{|c|}{$33.4 \%$} & \multicolumn{4}{|c|}{$22.3 \%$} & \multicolumn{4}{|c|}{$22.3 \%$} & \multicolumn{4}{|c|}{$22.5 \%$} \\
\hline
\end{tabular}

Table. 3. Antibacterial activity of the solvent extracts of five endophytic fungi isolated from Wattakaka volubilis (L. f.) Stapf

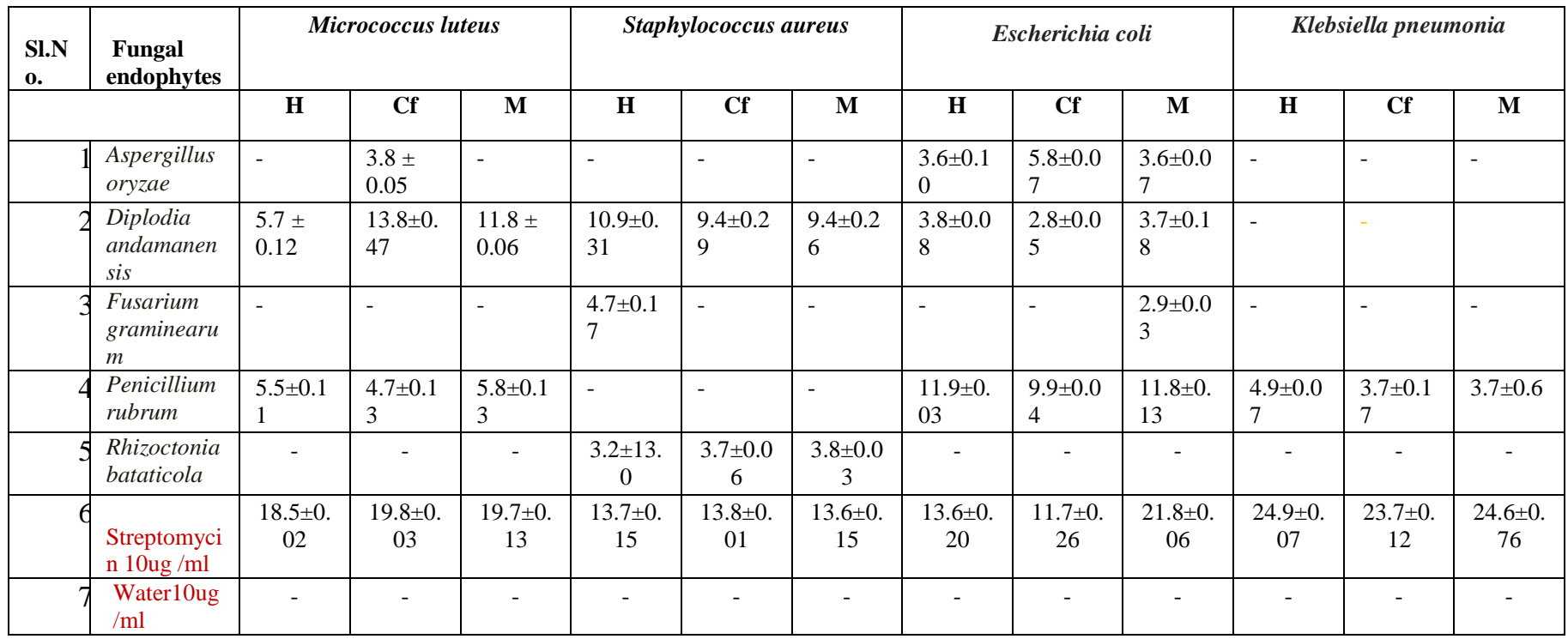

Activity was expressed as inhibitory zones (mm).The values are average of triplicates with standard errors.

*H-Hexane; CF-Chloroform; M-Methanol 


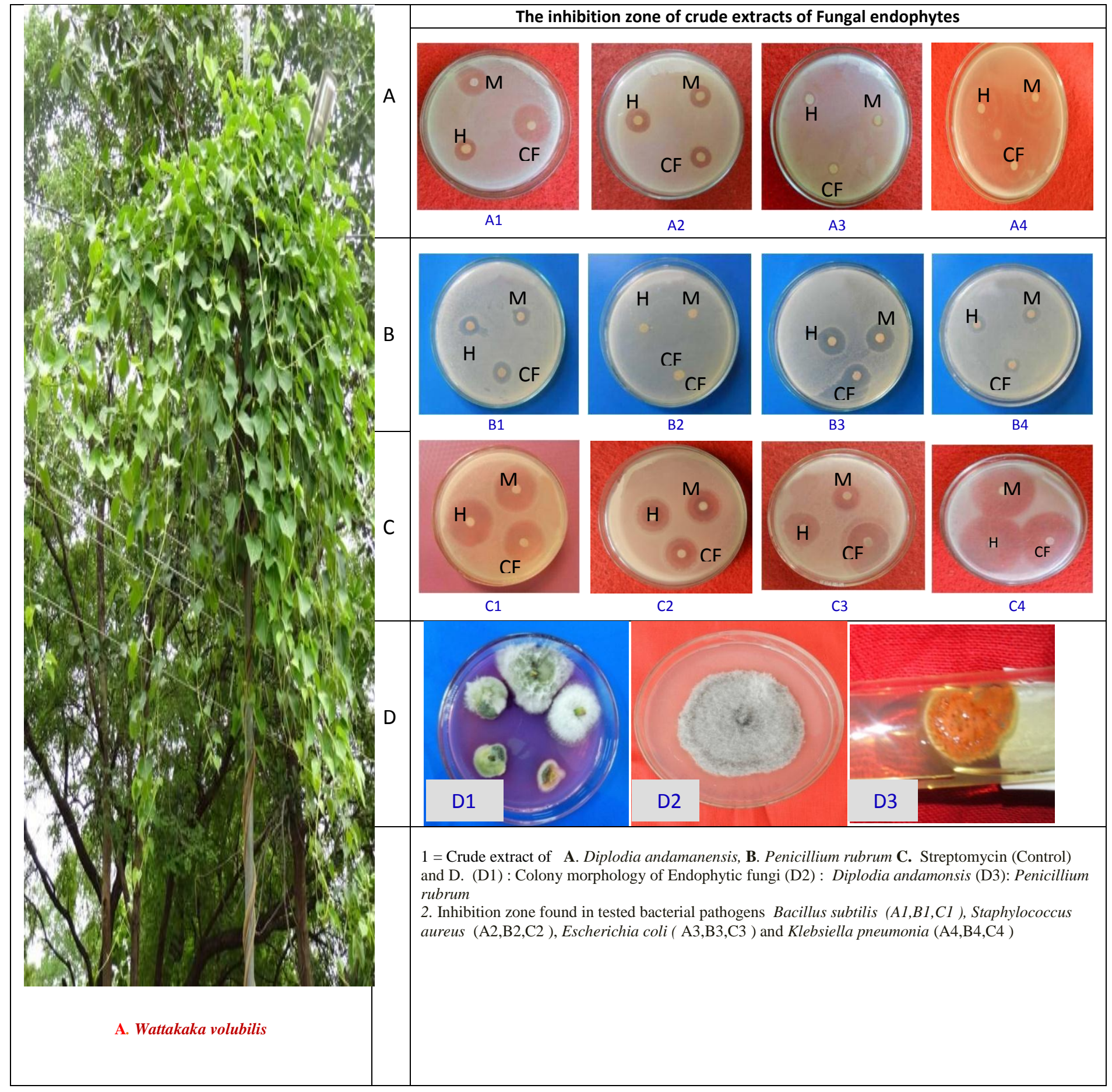

Figure 1. Antibacterial activity of Endophytic fungi from Wattakaka volubilis (L.f.) Stapf 